\title{
Allosteric initiation and regulation of catalysis with a molecular knot
}

DOI:

10.1126/science.aaf3673

\section{Document Version}

Accepted author manuscript

Link to publication record in Manchester Research Explorer

\section{Citation for published version (APA):}

Marcos Algaba, V., Stephens, A. J., Jaramillo Garcia, J., Nussbaumer, A. L., Woltering, S., Valero De La Cruz, A., Lemonnier, J-F., Vitorica-Yrezabal, I., \& Leigh, D. (2016). Allosteric initiation and regulation of catalysis with a molecular knot. Science, 352(6293), 1555-1559. https://doi.org/10.1126/science.aał3673

\section{Published in:}

Science

\section{Citing this paper}

Please note that where the full-text provided on Manchester Research Explorer is the Author Accepted Manuscript or Proof version this may differ from the final Published version. If citing, it is advised that you check and use the publisher's definitive version.

\section{General rights}

Copyright and moral rights for the publications made accessible in the Research Explorer are retained by the authors and/or other copyright owners and it is a condition of accessing publications that users recognise and abide by the legal requirements associated with these rights.

\section{Takedown policy}

If you believe that this document breaches copyright please refer to the University of Manchester's Takedown Procedures [http://man.ac.uk/04Y6Bo] or contact uml.scholarlycommunications@manchester.ac.uk providing relevant details, so we can investigate your claim.

\section{OPEN ACCESS}




\title{
Allosteric Initiation and Regulation of Catalysis with a Molecular Knot
}

\author{
Vanesa Marcos, Alexander J. Stephens, Javier Jaramillo-Garcia, Alina L. Nussbaumer, Steffen
}

L. Woltering, Alberto Valero, Jean-François Lemonnier, Iñigo J. Vitorica-Yrezabal, David A. Leigh*

School of Chemistry, University of Manchester, Oxford Road, Manchester, M13 9PL, UK

*Correspondence to: david.leigh@manchester.ac.uk

Abstract: Molecular knots occur in DNA, proteins and other macromolecules. However, the benefits that can potentially arise from tying molecules in knots are, for the most part, unclear. Here we report on a synthetic molecular pentafoil knot that allosterically initiates or regulates catalyzed chemical reactions by controlling the in situ generation of a carbocation formed through the knot-promoted cleavage of a carbon-halogen bond. The knot architecture is crucial to this function as it restricts the conformations that the molecular chain can adopt and prevents the formation of catalytically inactive species upon metal ion binding. Unknotted analogues are not catalytically active. Our results suggest that knotting molecules may be a useful strategy for reducing the degrees of freedom of flexible chains, enabling them to adopt what are otherwise thermodynamically inaccessible functional conformations.

One Sentence Summary: A synthetic molecular pentafoil knot is found to allosterically regulate or initiate catalyzed chemical reactions, requiring coordination to metal ions to generate a halide binding site that promotes formation of the key carbocation.

Molecular knots are found in circular DNA (1) and approximately $1 \%$ of proteins in the Protein Data Bank (PDB) (2), and form spontaneously in polymer chains of sufficient length and flexibility (3). Molecules with the topology of some of the simplest prime knots have been synthesized (4-13) but, although knots are fundamental elements of structure, the potential benefits that could arise from tying molecules in knots are mostly unclear (14-18). Recently, $\mathrm{Fe}(\mathrm{II})$ complexes of some synthetic molecular knots and links were found to strongly and selectively bind halide anions $\left(\mathrm{X}^{-}\right)$within their central cavities (19). This binding activity resembles a key feature of dehalogenase enzymes, which contain halide binding sites that facilitate the cleavage of carbon-halogen bonds $(20,21)$. Here we show that as little as $1 \mathrm{~mol} \%$ of a synthetic molecular pentafoil knot can induce Lewis acid catalyzed reactions by the in situ generation of a carbocation by carbon-halogen bond scission promoted by $\mathrm{CH}^{\cdots} \mathrm{X}^{-}$hydrogen bonding and long range metal-cation $\cdots \mathrm{X}^{-}$electrostatic interactions.

We previously reported the synthesis of a molecular pentafoil knot (a 5, knot in AlexanderBriggs notation (22)), inspired by Lehn's cyclic double helicates (23) but modified so as to be assembled, and the end groups connected, through imine chemistry $(24,25)$. The knot binds a chloride or bromide anion extremely strongly within its central cavity $\left(K_{\mathrm{Cl}^{-}}=3.6 \times 10^{10} \mathrm{M}^{-1}, K_{\mathrm{Br}^{-}}\right.$ $1.7 \times 10^{10} \mathrm{M}^{-1}$ in $\mathrm{MeCN}$ ) through a combination of $\mathrm{CH}^{\cdots} \cdot \mathrm{X}^{-}$hydrogen bonding and long range $\mathrm{Fe}(\mathrm{II}) \cdots \mathrm{X}^{-}$electrostatic interactions (19). However, attempts to remove the metal ions whilst maintaining the pentafoil knot topology proved unsuccessful due to the lability of uncoordinated imine bonds (25). We therefore investigated an alternative route to a metal-free pentafoil knot based on ring-closing olefin metathesis (RCM) of a tris(bipy) ligand strand (1) that had proved 
successful in the synthesis of a related Star of David catenane (26) (Fig. 1, detailed experimental procedures and full characterization data are given in Sections S1, S4-S8 of the Supplementary Material).

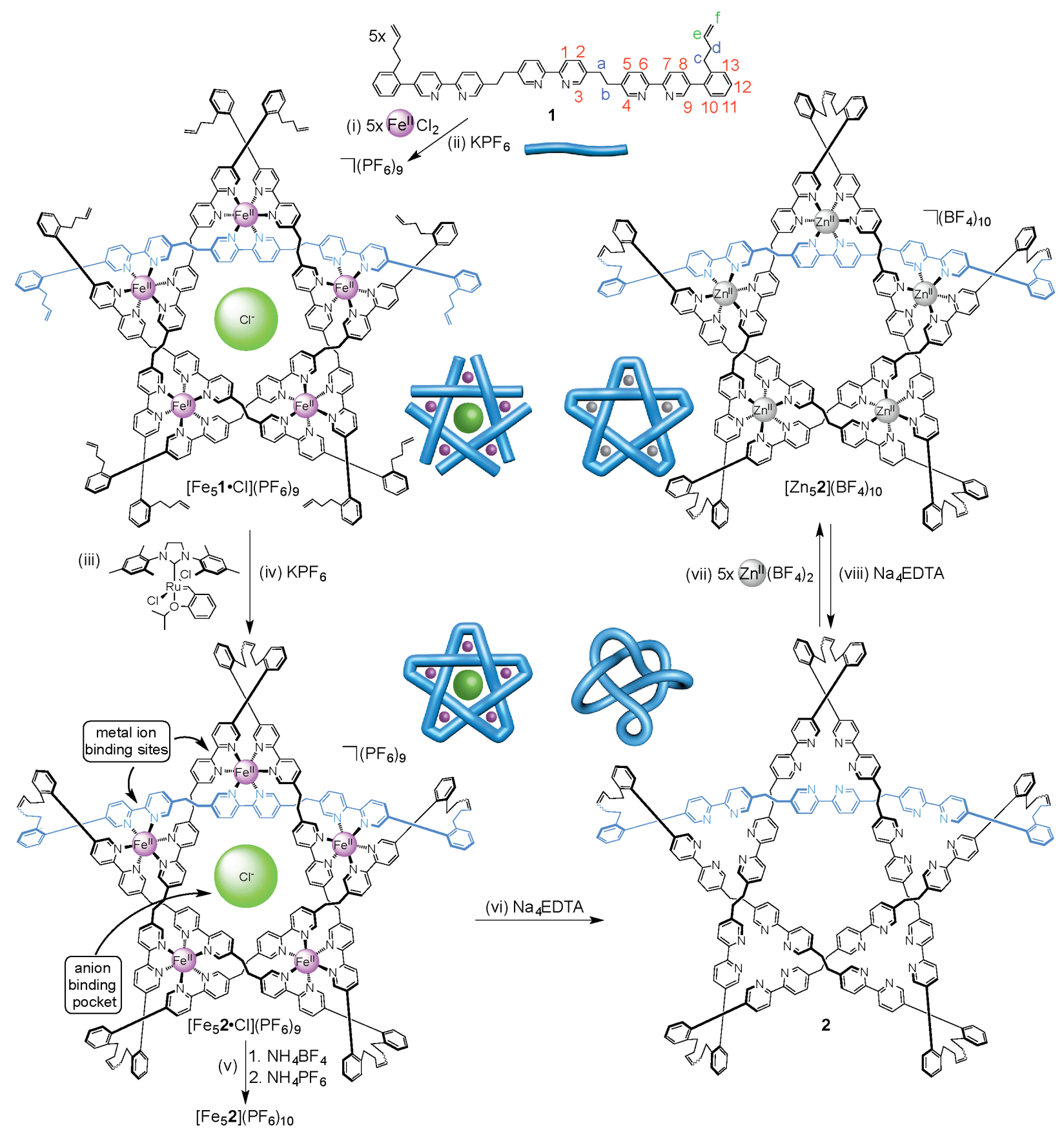

Fig. 1. Assembly of wholly organic pentafoil knot 2 and its reversible metallation with zinc(II) ions to form $\left[\mathrm{Zn}_{5} 2\right]\left(\mathrm{BF}_{4}\right)_{10}$. Reagents and conditions: (i) $\mathrm{FeCl}_{2}$, dimethylsulfoxide, $60{ }^{\circ} \mathrm{C}, 24 \mathrm{~h}$; (ii) saturated aqueous $\mathrm{KPF}_{6}$ solution $\left(89 \%\left[\mathrm{Fe}_{5} \mathbf{1}_{5} \cdot{ }^{\circ} \mathrm{Cl}\right]\left(\mathrm{PF}_{6}\right)_{9}\right.$ over two steps); (iii) HoveydaGrubbs $2^{\text {nd }}$ generation catalyst, 1,2-dichloroethane/nitromethane $(1 / 1), 60^{\circ} \mathrm{C}, 24 \mathrm{~h}$; (iv) saturated aqueous $\mathrm{KPF}_{6}$ solution $\left(98 \%\left[\mathrm{Fe}_{5} 2 \cdot \mathrm{Cl}\right]\left(\mathrm{PF}_{6}\right)_{9}\right.$ over two steps); (v) saturated aqueous $\mathrm{NH}_{4} \mathrm{BF}_{4}$ 
then saturated aqueous $\mathrm{NH}_{4} \mathrm{PF}_{6}\left(90 \%\left[\mathrm{Fe}_{5} 2\right]\left(\mathrm{PF}_{6}\right)_{10}\right)$; (vi) $\mathrm{Na}_{4}$ EDTA, acetonitrile/water (1/1), $80{ }^{\circ} \mathrm{C}, 4 \mathrm{~h}\left(69 \%\right.$ 2); (vii) $\mathrm{Zn}\left(\mathrm{BF}_{4}\right)_{2}$, dichloromethane/methanol $(3 / 1), 40{ }^{\circ} \mathrm{C}, 2 \mathrm{~h}(98 \%$ $\left.\left[\mathrm{Zn}_{5} 2\right]\left(\mathrm{BF}_{4}\right)_{10}\right)$; (viii) Na $\mathrm{NaDTA}_{4}$, acetonitrile/water (1/1), RT, 3 h (98 \% 2).

Heating ligand strand 1 with 1.25 equiv. of $\mathrm{FeCl}_{2}$ in dimethylsulfoxide (DMSO) at $60{ }^{\circ} \mathrm{C}$ resulted in an intensely-colored red-purple solution indicative of the formation of low-spin $\mathrm{Fe}$ (II)tris(bipy) complexes (Fig. 1, step i). After $24 \mathrm{~h}$ the pentameric circular helicate $\left[\mathrm{Fe}_{5} \mathbf{1}_{5}{ }^{\circ} \mathrm{Cl}\right]\left(\mathrm{PF}_{6}\right)_{9}$ was isolated in $89 \%$ yield by precipitation with aqueous $\mathrm{KPF}_{6}$ (Fig. 1, step ii) and characterized by ${ }^{1} \mathrm{H}$ nuclear magnetic resonance (NMR) spectroscopy (Fig. 2B) and electrospray ionization mass spectrometry (ESI-MS) (Figs. S48 and S49). The end groups of each ligand strand were successfully connected to form the pentafoil knot $\left[\mathrm{Fe}_{5} 2 \cdot \mathrm{Cl}\right]\left(\mathrm{PF}_{6}\right)_{9}$ by RCM using the HoveydaGrubbs second generation catalyst (Fig. 1, step iii) (27). The ${ }^{1} \mathrm{H}$ NMR spectrum of $\left[\mathrm{Fe}_{5} \mathbf{2} \cdot \mathrm{Cl}\right]\left(\mathrm{PF}_{6}\right)_{9}$ (Fig. 2C) confirms the absence of terminal alkene protons (cf. precursors $\mathbf{1}$ and $\left[\mathrm{Fe}_{5} \mathbf{1}_{5}{ }^{\circ} \mathrm{Cl}\right]\left(\mathrm{PF}_{6}\right)_{9}$, Figs. 2A and 2B) and also two distinct environments for some sets of aromatic protons (e.g. $\left.\mathrm{H}^{6}, \mathrm{H}^{7}, \mathrm{H}^{8}\right)$ as a result of restricted rotamerization around the phenyl-bipyridine bond after RCM.

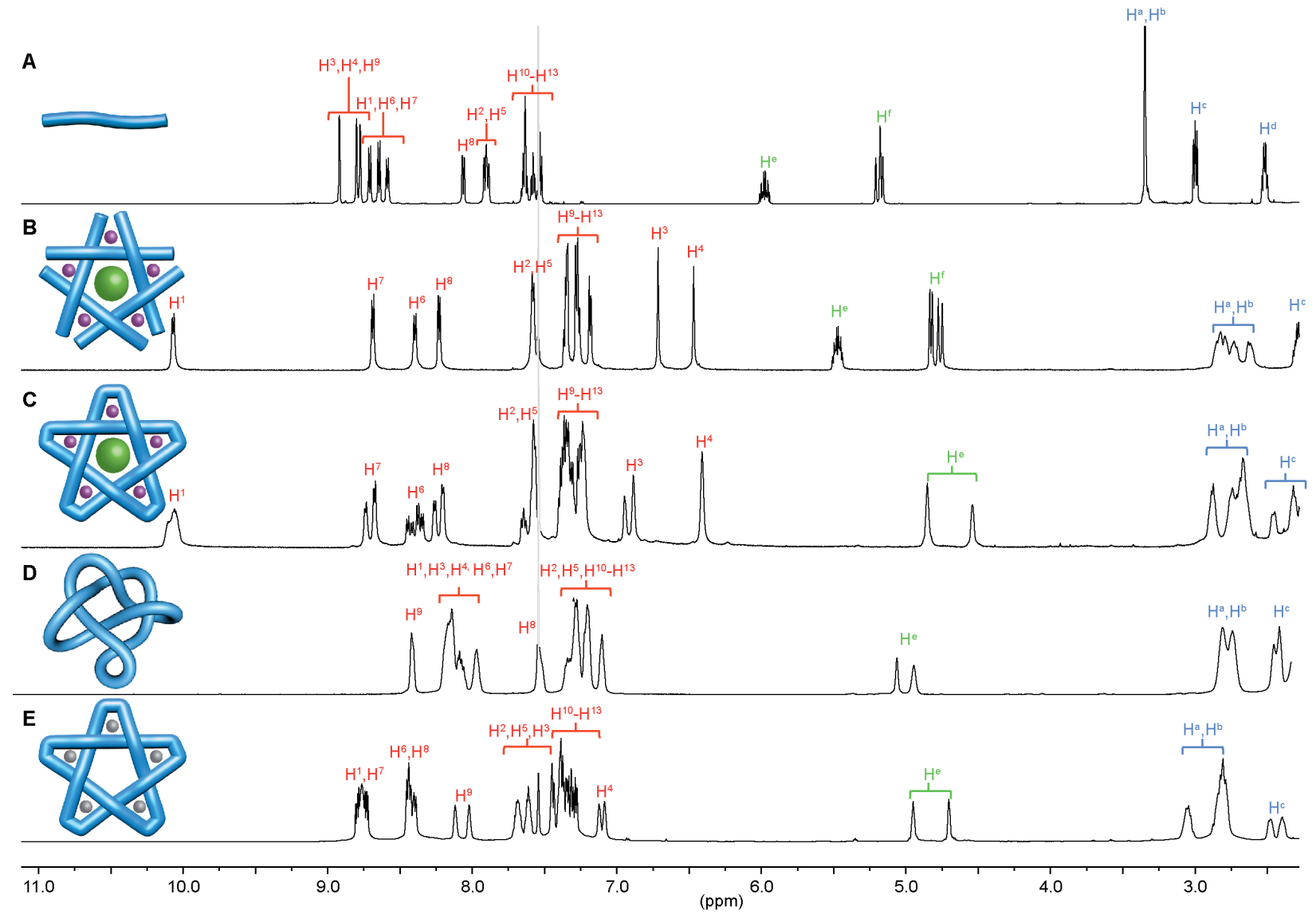

Fig. 2. Partial ${ }^{1} \mathrm{H}$ NMR spectra ( $600 \mathrm{MHz}, 298 \mathrm{~K}, \mathrm{CD}_{3} \mathrm{CN} / \mathrm{CDCl}_{3}$ (3/1): A) ligand 1; B) cyclic pentameric helicate $\left[\mathrm{Fe}_{5} \mathbf{1}_{5}{ }^{\bullet} \mathrm{Cl}\right]\left(\mathrm{PF}_{6}\right)_{9}$; C) Fe(II)-pentafoil knot $\left[\mathrm{Fe}_{5} 2^{\bullet} \mathrm{Cl}\right]\left(\mathrm{PF}_{6}\right)_{9}$; D) metal-free pentafoil knot 2; E) Zn(II)-pentafoil knot $\left[\mathrm{Zn}_{5} 2\right]\left(\mathrm{BF}_{4}\right)_{10}$. The signal assignments correspond to the labeling shown in Fig. 1. Signals from residual $\mathrm{CHCl}_{3}$ are shown in grey. 
Single crystals of $\left[\mathrm{Fe}_{5} \mathbf{2} \cdot \mathrm{Cl}\right]\left(\mathrm{PF}_{6}\right)_{9}$ were obtained by slow evaporation of a solution of the knot in a mixture of acetonitrile and toluene containing excess $\mathrm{NaBPh}_{4}$, and the solid-state structure determined by X-ray crystallography (Supplementary Section S8). The crystal structure (Fig. 3) confirmed the topology of the molecular pentafoil knot as a single 190-atom loop woven around five $\mathrm{Fe}(\mathrm{II})$ cations to create the five crossing points. As with the related imine-pentafoil knot, a chloride anion (present despite the large excesses of $\mathrm{PF}_{6}{ }^{-}$and $\mathrm{BPh}_{4}{ }^{-}$anions used in the purification and crystallization steps) is positioned within the central cavity of the pentafoil knot. The chloride ion is displaced by $\sim 1.47 \AA$ from the plane of the $\mathrm{Fe}$ (II) cations (Fig. 3B) and is in close contact with the ten electron-poor aromatic $\mathrm{CH}^{1}$ protons oriented towards the middle of the cavity $(\mathrm{CH} \cdots \mathrm{Cl}$ distance $2.46-2.85 \AA)$. The remaining anions are a $\sim 2: 1$ mixture of $\mathrm{PF}_{6}{ }^{-}$and $\mathrm{BPh}_{4}{ }^{-}$.
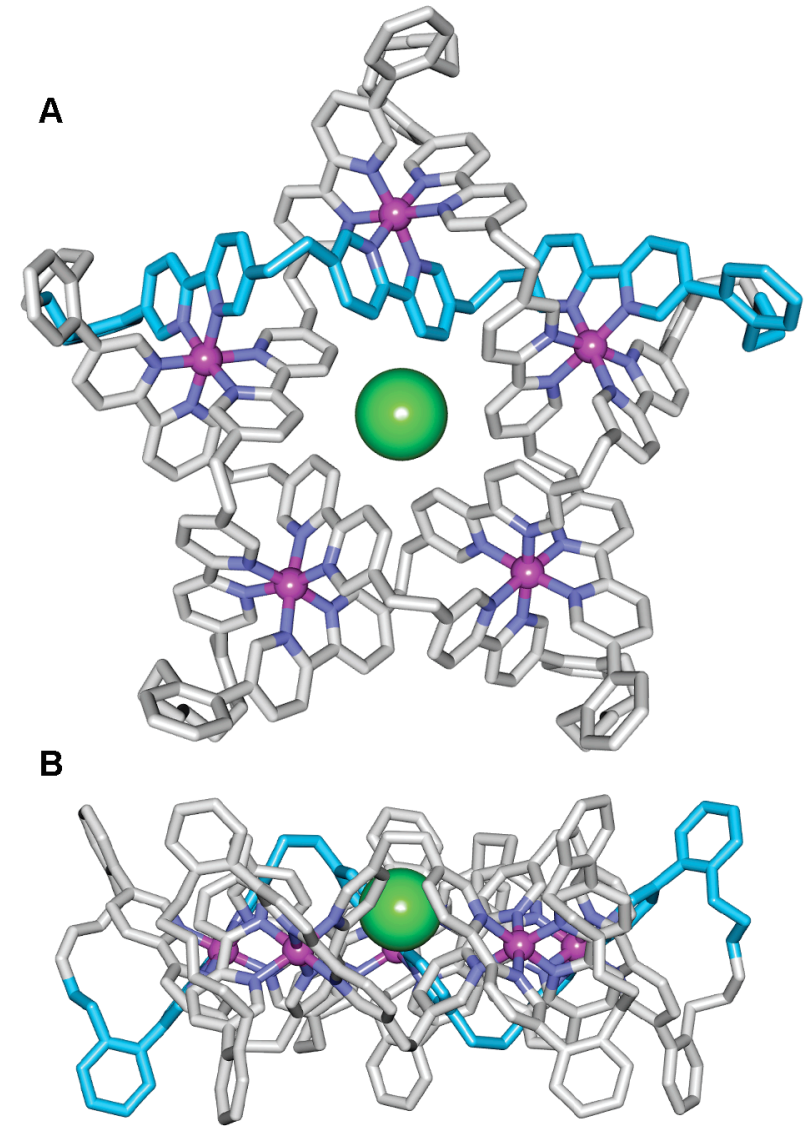

Fig. 3. X-ray crystal structure of pentafoil knot $\left[\mathrm{Fe}_{5} \mathbf{2}^{\cdot} \mathrm{Cl}\right]\left(\mathrm{PF}_{6}\right)_{6}\left(\mathrm{BPh}_{4}\right)_{3}$, shown as the $\Lambda^{5}$ enantiomer $\left(\Delta^{5}-\left[\mathrm{Fe}_{5} \mathbf{2} \cdot \mathrm{Cl}\right]\left(\mathrm{PF}_{6}\right)_{6}\left(\mathrm{BPh}_{4}\right)_{3}\right.$ is present in equal amounts in the unit cell). A) Viewed from above the central cavity of the knot. B) Viewed in the plane of the $\mathrm{Fe}(\mathrm{II})$ cations. Hydrogen atoms, solvent molecules and anions (except for the central $\mathrm{Cl}^{-}$) are omitted for clarity. The carbon atoms of one precursor ligand strand are colored light blue and the others light grey. N, dark blue; Fe, purple; Cl, green. Fe-Fe distances (A): 8.305(7), 8.241(6), 8.313(7), 8.389(7), 8.431(7). Fe-Fe-Fe angles $\left(^{\circ}\right)$ : 107.80(7), 106.86(7), 108.37(7), 108.14(7), 108.82(7). $\mathrm{CH} \cdots \mathrm{Cl}$ distances (A): 2.461, 2.527, 2.539, 2.553, 2.629, 2.653, 2.669, 2.677, 2.714, 2.858. Hydrogen 
bond distances were normalized using neutron diffraction data. Crystallographic data and experimental details of the structural refinement of $\left[\mathrm{Fe}_{5} 2 \cdot \mathrm{Cl}\right]\left(\mathrm{PF}_{6}\right)_{6}\left(\mathrm{BPh}_{4}\right)_{3}$ are provided in Section S8 of the Supplementary Information.

Unlike the imine pentafoil knot (24), the metal ions (and simultaneously the chloride ion) could be removed from $\left[\mathrm{Fe}_{5} \mathbf{2} \cdot \mathrm{Cl}\right]\left(\mathrm{PF}_{6}\right)_{9}$ by treatment with aqueous tetrasodium ethylenediaminetetraacetate ( $\mathrm{Na}_{4}$ EDTA) solution at $80{ }^{\circ} \mathrm{C}$, forming the metal-free knotted ligand 2 in $69 \%$ yield (Fig. 1, step vi; Supplementary Material, p. 9). The ${ }^{1} \mathrm{H}$ NMR spectrum of 2 in $\mathrm{CD}_{3} \mathrm{CN} / \mathrm{CDCl}_{3}$ (3/1) (Fig. 2D) is relatively broad in comparison to the metallated knot. Molecular modeling suggests that $\mathbf{2}$ does not exist in a single well-defined conformation and the broadness of the ${ }^{1} \mathrm{H}$ NMR spectrum is apparently a consequence of reptation (the thermal motion of long entangled polymer chains, which influences properties such as the viscous flow of amorphous polymers (28)) as the 190-atom-long knot backbone slowly slithers through transiently tightened loops and across over and under crossings. Despite possessing no elements of Euclidean chirality, the metal-free knot 2 is intrinsically chiral by virtue of its topology. The enantiomers could be separated by chiral high performance liquid chromatography (HPLC) (Supplementary Section S4) and the pentafoil knots of opposite handedness shown to have circular dichroism spectra of equal and opposite shape and sign (Fig. S22).

The iron-coordinated pentafoil knot binds a chloride or bromide ion strongly within its central cavity $\left(K_{\mathrm{Cl}^{-}} \sim 2.6 \times 10^{10} \mathrm{M}^{-1}(\mathrm{MeCN}), K_{\mathrm{Br}^{-}} 1.4 \pm 1.0 \times 10^{10} \mathrm{M}^{-1}(\mathrm{MeCN})\right.$, Supplementary Section S9). Nevertheless, the halide anion could be removed while leaving the Fe(II) ions in place, forming $\left[\mathrm{Fe}_{5} \mathbf{2}\right]\left(\mathrm{PF}_{6}\right)_{10}$, by treating $\left[\mathrm{Fe}_{5} \mathbf{2} \cdot \mathrm{Cl}\right]\left(\mathrm{PF}_{6}\right)_{9}$ or $\left[\mathrm{Fe}_{5} \mathbf{2} \cdot \mathrm{Br}\right]\left(\mathrm{PF}_{6}\right)_{9}$ first with saturated aqueous $\mathrm{NH}_{4} \mathrm{BF}_{4}$, which exchanges the majority of the anions - including the centrally bound halide-for $\mathrm{BF}_{4}^{-}$, and then saturated aqueous $\mathrm{NH}_{4} \mathrm{PF}_{6}$, which replaces the $\mathrm{BF}_{4}{ }^{-}$anions with $\mathrm{PF}_{6}^{-}$(19) (Fig. 1, step v; Supplementary Material, p. 7 and 8).

The reaction of tris(bipy) ligand strand 1 with divalent transition metal salts other than $\mathrm{Fe}(\mathrm{II})$ results in linear triple helicates, coordination polymers or complex product mixtures (29). Therefore it might seem that only iron(II)-complexed knots are accessible with this system. However, treatment of the metal-free pentafoil knot 2 with $\mathrm{Zn}\left(\mathrm{BF}_{4}\right)_{2}$ in a mixture of $\mathrm{CD}_{2} \mathrm{Cl}_{2} / \mathrm{CD}_{3} \mathrm{OD}(3 / 1)$ (Fig. 1, step vii), gave an initially broad ${ }^{1} \mathrm{H}$ NMR spectrum (Fig. S4) that sharpened after two hours at $40^{\circ} \mathrm{C}$, indicating rearrangement to a single molecular species. After workup, the formation of the zinc(II) coordinated pentafoil knot $\left[\mathrm{Zn}_{5} 2\right]\left(\mathrm{BF}_{4}\right)_{10}$ was confirmed by ${ }^{1}$ H NMR spectroscopy (Fig. 2E) and ESI-MS (Figs. S57 and S58). The restrictions on the chain conformation imposed by the topology of 2 prevent formation of linear triple helicates (as predominantly occurs with 1 and $\mathrm{Zn}$ (II) salts) and enable the ligand to adopt the higher energy circular helicate structure with zinc(II) ions that is thermodynamically inaccessible with $\mathbf{1}$. Zinc(II) ions typically exhibit much faster coordination kinetics than low-spin iron(II) ions and the $\mathrm{Zn}$ (II)-pentafoil knot could be demetallated to reform 2 (Fig. 1, step viii) more readily and under milder conditions than the Fe(II)-pentafoil knot (Fig. 1, step vi). The Zn(II)-pentafoil knot binds a chloride or bromide anion within its central cavity approximately a tenth as strongly as its $\mathrm{Fe}(\mathrm{II})$ counterpart $\left(K_{\mathrm{Cl}^{-}} \sim 2.9 \times 10^{9} \mathrm{M}^{-1}(\mathrm{MeCN}), K_{\mathrm{Br}^{-}} 7.7 \pm 2.0 \times 10^{8} \mathrm{M}^{-1}(\mathrm{MeCN})\right.$; Supplementary Section S9). 
Substantial recent catalysis research has leveraged anion-binding molecules to influence reactions by ion pairing (30) or, in some cases, promoting carbon-halogen bond cleavage (31). Even with the relatively modest anion binding affinities of the host molecules generally employed to date the approach has been shown to be effective across a range of reaction types (31). The empty cavity metallated pentafoil knots are amongst the strongest noncovalent binding synthetic hosts of $\mathrm{Cl}^{-}$and $\mathrm{Br}^{-}$known, readily sequestering traces of $\mathrm{Cl}^{-}$from the environment, including solvents and glassware. We wondered whether such a strong halide binder might be able to carry out reactions that have traditionally been the preserve of halophilic silver salts. We envisaged that the knot might be able to promote the formation of carbocations by stabilizing the $\mathrm{Br}^{-}$counter-anion formed by heterolytic carbon-bromine bond cleavage reactions.

We found that bromide ions bound within the cavities of either $\left[\mathrm{Fe}_{5} \mathbf{2} \cdot \mathrm{Br}\right]\left(\mathrm{PF}_{6}\right)_{9}$ or $\left[\mathrm{Zn}_{5} \mathbf{2} \cdot \mathrm{Br}\right]\left(\mathrm{BF}_{4}\right)_{9}$ react with methyl triflate to form bromomethane gas and the empty knots $\left[\mathrm{Fe}_{5} 2\right]\left(\mathrm{PF}_{6}\right)_{9} \mathrm{OTf}$ and $\left[\mathrm{Zn}_{5} 2\right]\left(\mathrm{BF}_{4}\right)_{9} \mathrm{OTf}$, respectively (Supplementary Section S2.1). This reaction could be used to recycle the halide-binding cavity of the knot in situ, for example using the $\mathrm{Zn}$ (II)-pentafoil knot as a catalyst for the hydrolysis of bromodiphenylmethane $\left(\mathrm{Ph}_{2} \mathrm{CHBr}\right)$ (Fig. 4A and Supplementary Section S2.2). Note that MeOTf does not promote the hydrolysis reaction in the absence of the knot. Other nucleophiles (e.g. $\mathrm{MeCN}$ ) also react efficiently with the catalytically generated benzhydryl $\left(\mathrm{Ph}_{2} \mathrm{CH}^{+}\right)$carbocation (Supplementary Section S2.3). 
A

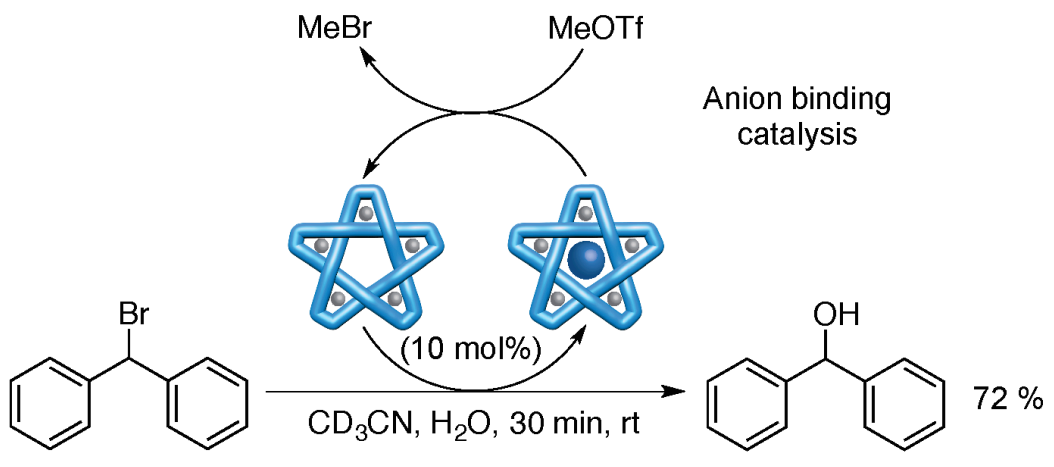

B
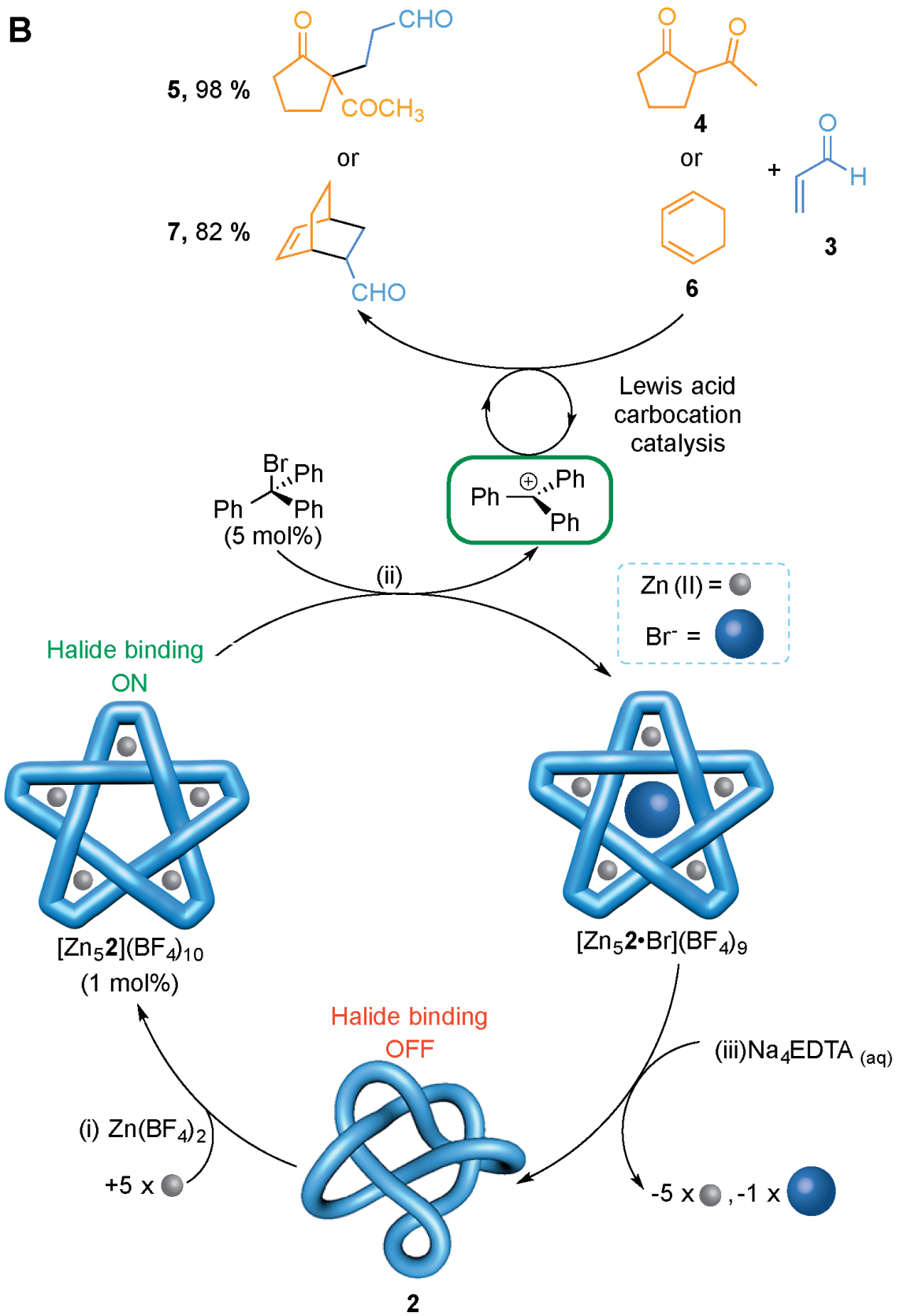
Fig. 4. Catalysis using a molecular knot. A) Catalytic hydrolysis of $\mathrm{Ph}_{2} \mathrm{CHBr}$. Reaction conditions: $\mathrm{Ph}_{2} \mathrm{CHBr}\left(2.0 \mu \mathrm{mol}, 1\right.$ equiv.), wet $\mathrm{CD}_{3} \mathrm{CN}(400 \mu \mathrm{L}),\left[\mathrm{Zn}_{5} 2\right]\left(\mathrm{BF}_{4}\right)_{10}(0.2 \mu \mathrm{mol}, 10$ mol\%), MeOTf (70 $\mu \mathrm{mol}, 35$ equiv.), room temperature (rt), $30 \mathrm{~min}, 72 \%$. B) Allosterically initiated catalysis of Michael addition and Diels-Alder reactions by in situ generation of a trityl cation via bromide abstraction using $\mathrm{Zn}(\mathrm{II})$-pentafoil knot $\left[\mathrm{Zn}_{5} 2\right]\left(\mathrm{BF}_{4}\right)_{10}$. Reaction conditions: (i) $2(0.75 \mu \mathrm{mol}, 1 \mathrm{~mol} \%$ with respect to 3$), \mathrm{Zn}\left(\mathrm{BF}_{4}\right)_{2}(3.71 \mu \mathrm{mol}), \mathrm{CH}_{2} \mathrm{Cl}_{2} / \mathrm{CH}_{3} \mathrm{OH}(3 / 1)(400 \mu \mathrm{l})$, $40{ }^{\circ} \mathrm{C}, 12 \mathrm{~h}\left(98 \%\left[\mathrm{Zn}_{5} 2\right]\left(\mathrm{BF}_{4}\right)_{10}\right)$. (ii) $0.3 \mathrm{M}$ solution of $3(0.075 \mathrm{mmol}, 1$ equiv. $), 4(0.11 \mathrm{mmol}$, 1.5 equiv.) or 6 (0.089 mmol, 1.5 equiv.), $\mathrm{Ph}_{3} \mathrm{CBr}(3.75 \mu \mathrm{mol}, 5 \mathrm{~mol} \%), \mathrm{CH}_{2} \mathrm{Cl}_{2}(250 \mu \mathrm{l}), \mathrm{RT}$, $8 \mathrm{~h}\left(98 \% 5\right.$; $82 \%$ 7). (iii) $\mathrm{Na}_{4} \mathrm{EDTA}_{(\mathrm{aq})} \mathrm{CH}_{3} \mathrm{CN} / \mathrm{H}_{2} \mathrm{O}(1 / 1), \mathrm{rt}, 3 \mathrm{~h}$ (quantitative 2). The use of a single knot enantiomer did not lead to chiral enrichment of the Michael addition or Diels-Alder products (presumably the trityl cation is ion-paired with a $\mathrm{BF}_{4}^{-}$anion rather than remaining associated with the knot).

In addition to acting as a catalyst in its own right, the metal-coordinated pentafoil knot could be used to generate other catalytic species, such as Lewis acidic trityl carbocations through anion abstraction (Fig. 4B). The Michael addition and Diels-Alder reactions of acrolein (3) with 2acetylcyclopentanone (4) and cyclohexadiene (6), respectively (Fig. 4B, Tables S1 and S2), can each be promoted by Lewis acidic carbocations $(32,33)$. We confirmed that neither of these reactions occurs in the absence of trityl bromide (Tables S1 and S2, entry 1) and proceed only slowly in the presence of trityl bromide alone (Tables S1 and S2, entry 2). Addition of $\mathrm{Fe}(\mathrm{II})$ (bipy) ${ }_{3}$, the basic metal coordination unit of the knot, does not increase the reaction rate above the background level (Tables S1 and S2, entries 3 and 4), nor does the addition of the tris(bipy) ligand strand $\mathbf{1}$, even in the presence of $\mathrm{FeCl}_{2}$ (any pentameric circular helicate formed would have a $\mathrm{Cl}^{-}$anion already strongly bound to the halide binding site) (Tables $\mathrm{S} 1$ and S2, entry 5). Neither the Fe(II)- nor Zn(II)-pentafoil knots ([Fe 2$]\left(\mathrm{PF}_{6}\right)_{10}$ and $\left.\left[\mathrm{Zn}_{5} 2\right]\left(\mathrm{BF}_{4}\right)_{10}\right)$ lead to catalysis of the reactions in the absence of trityl bromide (Tables S1 and S2, entries 11 and 14). However, in the presence of trityl bromide, both [ $\left.\mathrm{Fe}_{5} 2\right]\left(\mathrm{PF}_{6}\right)_{10}$ (Tables S1 and S2, entry 13) and $\left[\mathrm{Zn}_{5} 2\right]\left(\mathrm{BF}_{4}\right)_{10}$ (Tables S1 and S2, entry 15) initiate catalysis of the reactions effectively affording the endo-Diels-Alder (7) adduct in $62 \%$ (Fe(II)-knot) and $82 \%$ ( $\mathrm{Zn}(\mathrm{II})$-knot) and Michael adduct (5) in $83 \%$ (Fe(II)-knot) and $98 \%$ (Zn(II)-knot) yields, respectively (Figs. S6-S9).

Further evidence that the catalysis arises from in situ formation of the trityl cation by abstraction of a bromide anion into the knot cavity was provided by treating a solution of trityl bromide with $\left[\mathrm{Fe}_{5} 2\right]\left(\mathrm{PF}_{6}\right)_{10}$. UV-Vis spectroscopy confirmed the presence of the trityl carbocation (Fig. S14), showing its characteristic twin absorption features at $\lambda=425$ and $405 \mathrm{~nm}$, whilst ${ }^{1} \mathrm{H}$ NMR spectroscopy and mass spectrometry confirmed the contemporaneous formation of $\left[\mathrm{Fe}_{5} \mathbf{2} \cdot \mathrm{Br}\right]\left(\mathrm{PF}_{6}\right)_{9}$. In contrast, treating trityl bromide with the demetallated form of pentafoil knot $\mathbf{2}$ did not generate the carbocation (Fig. S20) and no catalysis was observed upon addition of 3 and 4 or 6 (Tables S1 and S2, entry 12).

The binding of one type of molecular species (an effector) to induce structural change and alter binding or catalysis at a second site-allosteric regulation-is a central part of the enzyme feedback loops biology uses to maintain homeostasis (34). Allosteric control of Friedel-Crafts reactions has previously been demonstrated by a synthetic catalyst using coordination control of hydrogen bonding sites (35). However, treating the metal-free knot 2 with iron(II) salts led to 
broad ${ }^{1} \mathrm{H}$ NMR spectra and complex product mixtures rather than simple reformation of [Fe $\mathrm{F}_{5}$ ], even under forcing conditions (Figs. S2 and S3). The kinetics of bipy exchange at low-spin iron(II) centers is apparently too slow, given the number of intermediates and alternative unproductive pathways, for folding of the knot to the highly ordered fivefold symmetrical form to proceed within a useful timeframe. In contrast, the fast and reversible coordination kinetics of zinc(II) ions allowed for allosteric initiation of the knot-promoted catalysis under mild conditions (Fig. 4B). Treating the metal-free knot 2 (inactive form) with $\mathrm{Zn}\left(\mathrm{BF}_{4}\right)_{2}$ in $\mathrm{CD}_{2} \mathrm{Cl}_{2} / \mathrm{CD}_{3} \mathrm{OD}(3 / 1)$ at $40{ }^{\circ} \mathrm{C}$ for up to $12 \mathrm{~h}$ (depending on the amount of $\mathrm{Zn}\left(\mathrm{BF}_{4}\right)_{2}$ employed) smoothly generated the halide binding $\mathrm{Zn}$ (II)-pentafoil knot $\left[\mathrm{Zn}_{5} 2\right]\left(\mathrm{BF}_{4}\right)_{10}$ (Fig. 4B, step i) (Fig. S5). Addition of a $0.3 \mathrm{M}$ solution of trityl bromide ( $5 \mathrm{~mol} \%$ ) and reagents 3 and $\mathbf{4}$ or $\mathbf{6}$, formed products 5 or $\mathbf{7}$ in excellent yield (98\% and $82 \%$, respectively, Fig. 4B, step ii) over 8 h, together with a fine suspension of $\left[\mathrm{Zn}_{5} \mathbf{2} \cdot \mathrm{Br}\right]\left(\mathrm{BF}_{4}\right)_{9}$ (Figs. S37 and S61). Filtration and washing with an aqueous solution of $\mathrm{Na}_{4}$ EDTA (Fig. 4B, step iii) quantitatively regenerated the demetallated knot, 2.

Our results suggest that tying molecules in knots may prove to be a useful strategy for reducing the degrees of freedom of flexible macrocycles and chains, enabling them to adopt otherwise thermodynamically inaccessible conformations that can perform useful tasks. By analogy it may be that one biological role of knotting is to prevent protein chains from adopting low energy, but inactive, folded states. The formation of a binding site by the organization of a long molecular strand by allosteric metal ion binding is also reminiscent of proteins. The use of a strongly halophilic, and chiral, metal-coordinated knot to promote the cleavage of carbon-halogen bonds may bring advantages of chemo- and stereoselectivity in chemical reactions traditionally promoted by silver salts.

\section{References and Notes:}

1. S. A. Wasserman, N. R. Cozzarelli, Biochemical topology: applications to DNA recombination and replication. Science 232, 951-960 (1986).

2. J. I. Sułkowska, E. J. Rawdon, K. C. Millett, J. N. Onuchic, A. Stasiak, Conservation of complex knotting and slipknotting patterns in proteins. Proc. Natl. Acad. Sci. U.S.A. 109, E1715-E1723 (2012).

3. M. D. Frank-Kamenetskii, A. V. Lukashin, A. V. Vologodskii, Statistical mechanics and topology of polymer chains. Nature 258, 398-402 (1975).

4. C. O. Dietrich-Buchecker, J.-P. Sauvage, A synthetic molecular trefoil knot. Angew. Chem., Int. Ed. Engl. 28, 189-192 (1989).

5. O. Safarowsky, M. Nieger, R. Fröhlich, F. Vögtle, A molecular knot with twelve amide groups-One-step synthesis, crystal structure, chirality. Angew. Chem., Int. Ed. 39, 1616-1618 (2000).

6. M. Feigel, R. Ladberg, S. Engels, R. Herbst-Irmer, R. Fröhlich, A trefoil knot made of amino acids and steroids Angew. Chem., Int. Ed. 45, 5698-5702 (2006).

7. J. Guo, P. C. Mayers, G. A. Breault, C. A. Hunter, Synthesis of a molecular trefoil knot by folding and closing on an octahedral coordination template. Nature Chem. 2, 218-222 (2010). 
8. P. E. Barran, H. L. Cole, S. M. Goldup, D. A. Leigh, P. R. McGonigal, M. D. Symes, J. Y. $\mathrm{Wu}, \mathrm{M}$. Zengerle, Active metal template synthesis of a molecular trefoil knot. Angew. Chem., Int. Ed. 50, 12280-12284 (2011).

9. N. Ponnuswamy, F. B. L. Cougnon, J. M. Clough, G. D. Pantoş, J. K. M. Sanders, Discovery of an organic trefoil knot. Science 338, 783-785 (2012).

10. T. Prakasam, M. Lusi, M. Elhabiri, C. Platas-Iglesias, J.-C. Olsen, Z. Asfari, S. CianferániSanglier, F. Debaene, L. J. Charbonnierè, A. Trabolsi, Simultaneous self-assembly of a [2]catenane, a trefoil knot, and a Solomon link from a simple pair of ligands. Angew. Chem., Int. Ed. 52, 9956-9960 (2013).

11. J.-F. Ayme, J. E. Beves, C. J. Campbell, D. A. Leigh, Template synthesis of molecular knots. Chem. Soc. Rev. 42, 1700-1712 (2013).

12. N. Ponnuswamy, F. B. L. Cougnon, G. D. Pantoș, J. K. M. Sanders, Homochiral and meso figure eight knots and a Solomon link. J. Am. Chem. Soc. 136, 8243-8251 (2014).

13. J.-F. Ayme, G. Gil-Ramírez, D. A. Leigh, J.-F. Lemonnier, A. Markevicius, C. A. Muryn, G. Zhang, Lanthanide template synthesis of a molecular trefoil knot. J. Am. Chem. Soc. 136, 13142-13145 (2014).

14. A. M. Saitta, P. D. Soper, E. Wasserman, M. L. Klein, Influence of a knot on the strength of a polymer strand. Nature 399, 46-48 (1999).

15. Y. Arai, R. Yasuda, K.-I. Akashi, Y. Harada, H. Miyata, K. Kinosita Jr., H. Itoh, Tying a molecular knot with optical tweezers. Nature 399, 446-448 (1999).

16. W. R. Taylor, A deeply knotted protein structure and how it might fold. Nature 406, 916-919 (2000).

17. J. R. Wagner, J. S. Brunzelle, K. T. Forest, R. D. Vierstra, A light-sensing knot revealed by the structure of the chromophore-binding domain of phytochrome. Nature 438, 325-331 (2005).

18. Y. Liu, Y. Ma, Y. Zhao, X. Sun, F. Gándara, H. Furukawa, Z. Liu, H. Zhu, C. Zhu, K. Suenaga, P. Oleynikov, A. S. Alshammari, X. Zhang, O. Terasaki, O. M. Yaghi, Weaving of organic threads into a crystalline covalent organic framework. Science 351, 365-369 (2016).

19. J.-F. Ayme, J. E. Beves, C. J. Campbell, G. Gil-Ramírez, D. A. Leigh, A. J. Stephens, Strong and selective anion binding within the central cavity of molecular knots and links. J. Am. Chem. Soc. 137, 9812-9815 (2015).

20. R. M. de Jong, B. W. Dijkstra, Structure and mechanism of bacterial dehalogenases: different ways to cleave a carbon-halogen bond. Curr. Opin. Struct. Biol. 13, 722-730 (2003).

21. L. Tang, D. E. Torres Pazmiño, M. W. Fraaije, R. M. de Jong, B. W.Dijkstra, D. B. Janssen, Improved catalytic properties of halohydrin dehalogenase by modification of the halide-binding site. Biochemistry 44, 6609-6618 (2005).

22. J. W. Alexander, G. B. Briggs, On types of knotted curves. Ann. Math. 28, 562-586 (19261927).

23. B. Hasenknopf, J.-M. Lehn, B. O. Kneisel, G. Baum, D. Fenske, Self-assembly of a circular double helicate. Angew. Chem., Int. Ed. 35, 1838-1840 (1996). 
24. J.-F. Ayme, J. E. Beves, D. A. Leigh, R. T. McBurney, K. Rissanen, D. Schultz, A synthetic molecular pentafoil knot. Nature Chem. 4, 15-20 (2012).

25. J.-F. Ayme, J. E. Beves, D. A. Leigh, R. T. McBurney, K. Rissanen, D. Schultz, Pentameric circular iron(II) double helicates and a molecular pentafoil knot. J. Am. Chem. Soc. 134, 9488-9497 (2012).

26. D. A. Leigh, R. G. Pritchard, A. J. Stephens, A Star of David catenane, Nat. Chem. 6, 978-982 (2014).

27. S. B. Garber, J. S. Kingsbury, B. L. Gray, A. H. Hoveyda, Efficient and recyclable monomeric and dendritic Ru-based metathesis catalysts. J. Am. Chem. Soc. 122, 8168-8179 (2000).

28. P. G. De Gennes, Reptation of a polymer chain in the presence of fixed obstacles. J. Chem. Phys. 55, 572-571 (1971).

29. B. Hasenknopf, J.-M. Lehn, N. Boumediene, E. Leize, A. Van Dorsselaer, Kinetic and thermodynamic control in self-assembly: sequential formation of linear and circular helicates. Angew. Chem., Int. Ed. 37, 3265-3268 (1998).

30. K. Brak, E. N. Jacobsen, Asymmetric ion-pairing catalysis. Angew. Chem., Int. Ed. 52, 534561 (2013).

31. N. Busschaert, C. Caltagirone, W. Van Rossom, P. A. Gale, Applications of supramolecular anion recognition. Chem. Rev. 115, 8038-8155 (2015).

32. J. Bah, J. Franzén, Carbocations as Lewis acid catalysts in Diels-Alder and Michael addition reactions. Chem. Eur. J. 20, 1066-1072 (2014).

33. V. R. Naidu, S. Ni, J. Franzén, The carbocation: a forgotten Lewis acid catalyst.

ChemCatChem 7, 1896-1905 (2015).

34. T. Traut, Allosteric Regulatory Enzymes (Springer, New York, 2008).

35. C. M. McGuirk, J. Mendez-Arroyo, A. M. Lifschitz, C. A. Mirkin, Allosteric regulation of supramolecular oligomerization and catalytic activity via coordination-based control of competitive hydrogen-bonding events. J. Am. Chem. Soc. 136, 16594-16601 (2014).

36. J. Bah, V. R. Naidu, J. Teske, J. Franzén, Carbocations as Lewis acid catalysts: reactivity and scope. Adv. Synth. Catal. 357, 148-158 (2015).

37. B. Anxionnat, A. Guérinot, S. Reymond, J. Cossy. $\mathrm{FeCl}_{3}$-catalyzed Ritter reaction. Synthesis of amides, Tetrahedron Lett. 50, 3470-3473 (2009).

38. G. M. Sheldrick. SADABS, Empirical absorption correction program based upon the method of Blessing (University of Göttingen, 1995).

39. R. H. Blessing. An empirical correction for absorption anisotropy. Acta Crystallogr. A51, 33-38 (1995).

40. G. M. Sheldrick. A short history of SHELX. Acta Crystallogr. A64, 112-122 (2008).

41. G. M. Sheldrick. Crystal structure refinement with SHELXL. Acta Crystallogr. C71, 3-8. (2015) 
42. G. M. Sheldrick, SHELXT - Integrated space-group and crystal-structure determination. Acta Crystallogr. A71, 3-8 (2015).

43. O. V. Dolomanov, L. J. Bourhis, R. J. Gildea, J. A. K. Howard, H. Puschmann. OLEX2: a complete structure solution, refinement and analysis program. J. Appl. Cryst. 42, 339-341 (2009).

44. PLATON, A Multipurpose Crystallographic Tool (Utrecht University, Utrecht, The Netherlands, 2008).

45. J. L. Sessler, D. An, W. S. Cho, V. Lynch, M. Marquez. Calix[4]bipyrrole—a big, flexible, yet effective chloride-selective anion receptor. Chem. Commun. 540-542 (2005).

46. OriginPro 8.51 from OriginLab ${ }^{\odot}$.

Acknowledgments This research was funded by the European Research Council (Advanced grant no. 339019) and the European Union's seventh Framework Program (FP7-PEOPLE-2013ITN-607602 'Hierarchical Self Assembly of Polymeric Soft Systems' SASSYPOL). The authors thank the EPSRC National Mass Spectrometry Service Centre (Swansea, U.K.) for highresolution mass spectrometry. CCDC-1443084 contains the supplementary crystallographic data for this paper. These data can be obtained free of charge via www.ccdc.cam.ac.uk/conts/retrieving.html (or from the Cambridge Crystallographic Data Centre, 12 Union Road, Cambridge CB21EZ, UK; fax: (+44)1223-336-033; or deposit@ccdc.cam.ac.uk).

\section{Supplementary Materials:}

Materials and Methods

Figures S1-S66

Tables S1-S3

References (36-46) 